\title{
Lukács e a Especificidade da Questão da Ética: Apontamento Sobre a Crítica Lukacsiana ao Direito e à Moral
}

\section{Vitor Sartori}

Professor-adjunto da UFMG e professor do Programa de Pós-Graduação em Direito da UFMG. vitorbsartori@gmail.com

\section{Resumo}

Passando pela teorização lukacsiana sobre a ética, mostraremos, a partir da metodologia da "análise imanente" desenvolvida por José Chasin, como 0 autor, ao criticar o stalinismo, critica também 0 Direito e a moral. Procuraremos mostrar como a questão da ética aparece no autor da Ontologia do ser socialao se ter três pontos por centrais que estão concatenados em torno da questão da ética: 1) um acerto de contas com autores da filosofia clássica alemã (Kant e Hegel); 2) um questionamento à vida cotidiana na sociedade capitalista; e, por fim, 3) uma crítica ao Direito.

Palavras-chave: Direito. Ética. Lukács, ontologia do ser social.

\section{Lukács and the Specificity of the Matter of Ethics: Notes on the Lukacian Critic on Law and Moral}

\begin{abstract}
Taking on account Lukács' last works, we intend to show, taking as a departing point the "immanent analysis", developed by José Chasin, how the Hungarian Marxist criticizes Stalinism by criticizing Moral and Law. We intend to make it clear that: the matter of Ethics is key to the author of the Ontology of social being in three ways: 1) when he criticizes the main authors of German classic Philosophy (Kant and Hegel); 2) when he criticizes daily life in the capitalist society; and, finally, 3 when emerges the critic of Law in his thought.
\end{abstract}

Keywords: Law. Ethics. Lukács, ontology of social Being. 
Recebido em: 8/11/2016

Revisões requeridas em: 27/9/2017

Aceito em: 21/11/2017

\section{Sumário}

1 Introdução. 20 lugar da ética e da teorização de Lukács no marxismo e na filosofia do Direito. 3 Lukács contra o stalinismo: a questão da ética e da democracia. 4 A questão ética diante da filosofia clássica alemã e da política. 5 Moral e ética em Lukács: uma inflexão diante de Kant e de Hegel. 6 Ética, ontologia e a questão do "que fazer" em Lukács. 7 Ética, Direito e a crítica ao capitalismo em Lukács. 8 Apontamentos finais: ética e crítica ao Direito em Lukács. 9 Referências. 


\section{INTRODUÇÃO}

No presente texto pretendemos tratar de uma questão que é bastante valorizada, embora também negligenciada, no campo da filosofia do Direito - aquela da ética. Ninguém pode negar que na teoria e na filosofia do Direito contemporâneas há bastantes estudos sobre a relação entre Direito e moral (MACEDO, 2011); igualmente inegável é a influência destas teorizações em certas tendências judiciais no Brasil (STRECK, 1999). Tratar da relação entre Direito, moral e argumentação tende a ser um percurso bastante comum para que se escape do "formalismo", que tende a marcar, de um modo ou de outro, o Direito (RODRIGUES, 2013). Ou seja, a questão da moral e da ética perpassam a fundamentação jusfilosófica do Direito; no entanto, por mais que autores como Dworkin (2014) venham a distinguir moral e ética, pode-se afirmar que a relação da eticidade com a moralidade - salvo no caso de Honneth $(2002,2015)$ e, até certo ponto, Habermas $(1997,2003)$, que não são propriamente juristas - não vem a ser central no campo da teoria do Direito. É muito mais usual uma ênfase que perpassa a filosofia moral com uma abordagem influenciada pela filosofia da linguagem (MUNOZZ, 2008). Isto é, a abordagem da teoria do Direito, em geral, escapa da questão acerca da eticidade (Sittlichkeit) por meio de uma teoria moral. Autores que abordem a questão, como Honneth e Habermas - mas principalmente o primeiro -, por sua vez, não têm como centro ordenador de suas teorias a análise e a crítica do Direito, embora a questão possa ser desenvolvida a partir de suas teorias, principalmente ao se ter em conta o campo do Direito constitucional (GOMES; CATTONI DE OLIVEIRA, 2014). No presente texto pretendemos abordar, a partir da "análise imanente"1 do texto do marxista húngaro György Lukács, a temática de um modo bastante distinto.

\footnotetext{
${ }^{1}$ Segundo José Chasin, "tal análise, no melhor da tradição reflexiva, encara o texto - a formação ideal - em sua consistência autossignificativa, aí compreendida toda a grade de vetores que o conformam, tanto positivos como negativos: o conjunto de suas afirmações, conexões
} 
Partiremos de uma análise que se diferencia, simultaneamente, da teoria social de um Habermas e de um Honneth e da teoria do Direito. Esta última, em geral, traz uma abordagem por meio da teorização sobre a linguagem (o que acontece de modo bastante acentuado na Teoria do agir comunicativo também). Buscaremos explicitar, em Lukács, uma possível fundamentação marxista da questão, posto que, em verdade, aquele que mais se destacou no campo da teorização marxista sobre o Direito foi Pachukanis (1988), que rechaçou que este fosse um ponto de partida interessante. Opor-nos-emos, pois, a muitas vertentes do pensamento jusfilosófico, procurando explicitar a possibilidade de um tratamento marxista contra-hegemônico dentro do próprio marxismo. Este artigo tem como objetivo explicitar o tratamento lukacsiano da questão da ética e do Direito, para que fique claro como o autor húngaro pode contribuir à filosofia do Direito.

Para isso, procuraremos expor a questão a partir da análise imanente da derradeira obra do marxista húngaro György Lukács, que pode ser considerado o maior marxista do século 20 (MÉSZÁROS, 1972), e cuja profundidade filosófica, acreditamos, pode fazer frente ao melhor da filosofia do século 20 e mesmo do 21 (TERTULIAN, 2016). Cremos que seja proveitoso teorizar a questão acerca da ética, do Direito e da moral no autor para que uma versão alternativa desta temática tão importante, ao menos em seus delineamentos mais gerais, esteja disponível ao estudioso de filosofia e de teoria e filosofia do Direito. Se a influência da hermenêutica filosófica é também perceptível neste campo (STRECK, 1999), pretendemos expor, em linhas gerais, aquilo que o melhor do marxismo pode

e suficiências, como as eventuais lacunas e incongruências que o perfaçam. Configuração esta que em si é autônoma em relação aos modos pelos quais é encarada, de frente ou por vieses, iluminada ou obscurecida no movimento de produção do para-nós que é elaborado pelo investigador, já que, no extremo e por absurdo, mesmo se todo o observador fosse incapaz de entender o sentido das coisas e dos textos, os nexos ou significados destes não deixariam, por isso, de existir [...]” (2009, p. 26). 
oferecer sobre a questão, inclusive, na medida em que há certa "ausência-presença” de Marx nesta última tradição (SARTORI, 2016c). Mesmo que não se concorde com as posições de Lukács, acreditamos que este traz uma abordagem distinta da tradicional quando se trata de marxismo e, neste sentido, seu estudo pode ser bastante proveitoso.

Se noutro lugar já se tratou da crítica lukacsiana à moral e sobre a insuficiência da abordagem pachukaniana sobre a mesma questão da ética (SARTORI, 2015a), aqui pretendemos trazer, a partir da análise imanente do texto lukacsiano, um enfoque que recaia sobre a ética, a eticidade e sobre a importância da última no pensamento maduro de György Lukács. Procuraremos traçar os delineamentos gerais da questão ao estabelecer como a esfera aparece, em sua especificidade, na obra lukacsiana. Deste modo, mesmo para aqueles que não concordem com a metodologia marxista, pode-se ver com cuidado uma análise distinta da usual para uma questão que vem sendo vista como central à filosofia e à teoria do Direito. Nosso artigo pretende justamente trazer à tona, a partir da metodologia da análise imanente, esta análise.

Com isso, procuraremos mostrar como a questão da ética aparece em Lukács com uma contraposição ao stalinismo. Mostraremos, também, como o autor traz, a partir da problemática da ética, uma defesa da democracia e uma crítica ao Direito e à moral. Acreditamos que isto possa ser essencial, não para que as posições do autor húngaro sejam tomadas inelutavelmente como corretas, mas para que se perceba: um marxista como Lukács trata de questões centrais à filosofia do Direito contemporânea, sendo proveitoso, assim, o debate de sua obra. Ele também traz uma compreensão sofisticada sobre a correlação entre as diversas esferas do ser social, sendo interessante, aos marxistas e aos não marxistas, enxergar o modo pelo qual isto se dá no autor. 


\section{LUGAR DA ÉTICA E DA TEORIZAÇÃO DE LUKÁCS NO MARXISMO E NA FILOSOFIA DO DIREITO}

Em verdade, a questão da ética vem sendo bastante valorizada pelos estudiosos de Lukács. Sua importância vem sendo destacada para a compreensão da obra do autor húngaro (TERTULIAN, 2010; SARTORI, 2015a); em grande parte, isto vem ocorrendo ao se ter em conta o valor dos apontamentos ontológicos do autor (mormente presentes em sua Ontologia), que podem ajudar para compreender a especificidade das distintas esferas do ser social. Dentre tais esferas, podemos destacar, no que diz respeito ao tema que abordamos aqui, aquelas do Direito, da ética e da moral. Esta compreensão da diferença específica e da indissociabilidade das esferas do ser social, em verdade, é central tanto para a Estética quanto para a Ontologia do autor húngaro, suas grandes obras de maturidade (TERTULIAN, 2007b). ${ }^{2}$ É preciso que se diga desde já: não foi incomum uma abordagem "marxista" que, contrariamente ao cuidado e ao rigor lukacsiano, se satisfizesse em trazer e apontar influência da luta de classes em determinado campo para que tudo estivesse resolvido em um tratamento "marxista" das questões sociais (SARTORI, 2016b). Também foi comum certo "marxismo" que trouxesse determinada relação imediata entre teoria e prática, como ocorre, de acordo com Lukács, no stalinismo (LUKÁCS, 1972). O autor húngaro, por seu turno, procura ir bastante além. Busca a compreensão da tessitura complexa da sociedade

\footnotetext{
${ }^{2}$ Como aponta Tertulian: "não se deve esquecer que a Ontologia do ser social nasceu como pano de fundo de uma vasta pesquisa consagrada aos problemas da Ética. Depois de muitos anos de pesquisa (e o volume Kleine Notizen zur Ethik, anunciado pelo Arquivo Lukács, deveria dar testemunho disso), ele se dava conta de que não era possível estabelecer a especificidade da atividade ética fora de uma reflexão de conjunto, em contraposição aos componentes principais da vida da sociedade (economia, política, direito, religião, arte, filosofia): a Ontologia do ser social representa a concretização desse vasto programa totalizante, destinado a preparar a Ética (que infelizmente não virá a ser realizada)” (TERTULIAN, 2010, p. 390).
} 
e das potencialidades e limitações de cada complexo social específico. E, podemos dizer: somente em meio a este estudo veio o autor a procurar um tratamento marxista à ética. ${ }^{3}$

Tal temática, acreditamos, pode ter um papel bastante importante no desenvolvimento conjunto, a partir da obra lukacsiana, de uma crítica ao Direito, à moral e ao stalinismo, crítica esta, cremos, pode ajudar a trazer uma visão marxista e cuidadosa para o campo da filosofia do Direito. Neste sentido, é bem verdade que a abordagem lukacsiana é explicitamente crítica ao Direito; e explorar tal perspectiva, nem que seja para fins comparativos, pode ser bastante importante para uma reflexão sobre a esfera jurídica e sobre o tratamento marxista desta; se a capacidade de questionar é essencial em uma abordagem reflexiva, a crítica da própria posição "profissional” do jurista, que é trazida por Lukács, também pode o ser. Ao tratar da especificidade de cada complexo social, o autor da Ontologia procura iluminar as limitações e potencialidades de cada "profissão". Acreditamos que, a partir do momento em que a "perspectiva interna" começa a ser valorizada na teoria do Direito, isto pode ser interessante, nem que seja para traçar paralelos entre distintas teorias que procuram tratar com cuidado o campo jurídico. ${ }^{4}$

${ }^{3}$ Nicolas Tertulian chega a afirmar que "a última grande obra de Lukács, Zur Ontologie des gesellschaftlichen Seins, é inspirada pela convicção de que uma regeneração da práxis socialista passa inevitavelmente pela ruptura com o marxismo imobilizado, que havia garantido por seu necessitarismo e por seu 'economicismo', tanto o oportunismo da socialdemocracia anterior à primeira guerra mundial, quanto, sobre um outro plano, o stalinismo. Lukács aí propõe restituir à política, ao Direito, à moralidade, a ética, o lugar que lhes corresponde na topografia da sociedade, demonstrando que a densidade e a complexidade do tecido social excluem toda codificação a partir de normas abstratas. Gigantesca empreitada histórica de regulação autoritária da vida social, o stalinismo não é uma encarnação do marxismo, mas sua perversão teórica e prática” (TERTULIAN, 2007a, b, p. 39).

${ }^{4}$ Segundo Hart, “o contraste seguinte em termos de aspecto 'interno’ e 'externo' das regras [...] pode servir para marcar o que dá a esta distinção a sua grande importância para a compreensão, não só do direito, mas da estrutura da sociedade. Quando um grupo social tem certas regras de conduta, este fato confere uma oportunidade a muitos tipos de asserção intimamente relacionados, embora diferentes; porque é possível estar preocupado com as regras, quer apenas como observador, que as não aceita ele próprio, quer como membro 
Deste modo, neste pequeno texto procuraremos traçar esta questão ao trazer a posição do marxista húngaro acerca da especificidade da ética ante o Direito e a moral. Acreditamos que isto pode ser de grande relevo na medida em que a teoria moral vem sendo essencial para o desenvolvimento da teoria do Direito (MACEDO, 2011), de tal modo que a confluência entre uma teoria moral e a jurídica vem sendo apontada por grandes expoentes da filosofia do Direito, tal qual Dworkin, como algo essencial para se "levar os direitos a sério" (DWORKIN, 2007, 2010, 2014). Neste sentido, procuraremos expor os delineamentos de uma visão oposta, mas que perpassa questões que vêm sendo vistas como essenciais ao melhor da filosofia e da teoria do Direito. Lukács talvez possa contribuir bastante neste sentido (SARTORI, 2015b).

Deste modo, desde já vale iniciar mencionando que o marxista húngaro é claro em seus apontamentos, trazendo um sentido oposto àquilo que tende a prevalecer na teoria e na filosofia do Direito contemporâneas, ${ }^{5}$ as quais, quase que "naturalmente", tendem a ver o Direito enquanto um ponto de partida bastante importante para o desenvolvimento democrático; a perspectiva marxista, trazida pelo autor, a rigor, tem uma abordagem distinta, a qual, mesmo que para fins comparativos, deve ser compreendida por aqueles que estudam a filosofia do Direito. Nesta direção, afirma Lukács: "período stalinista: em vez do desenvolvimento avante da moral (e Direito) para a ética, reconversão da moral em Direito" (LUKÁCS, 2015, p. 173). Se é claro que no século 21 é essencial para as perspectivas críticas um acerto de contas com o século 20 e com o "socialismo"

de um grupo que a usa como guias de conduta. Podemos chamar-lhes os 'pontos de vista' respectivamente 'interno' e 'externo”' (HART, 2003, p. 99). Para a importância da questão, influenciada pela filosofia da linguagem em seu desenvolvimento, ver. MUÑOZ, 2008.

${ }^{5}$ Suas Notas sobre uma ética são bastante fragmentárias, tratando-se somente de "apontamentos" e nada mais. São uma importante indicação dos rumos que o projeto de uma ética poderia tomar em Lukács. Podem, no entanto, constar indicações preciosas para um desenvolvimento substancial do marxismo e da questão ética. 
soviético $^{6}$, talvez seja preciso deixar claro que, dentro da própria tradição marxista, há autores que, talvez, possam ajudar efetivamente neste sentido. O embate do autor da Ontologia do ser social com o Direito, talvez possa ser importante para a compreensão da complexidade da questão (SARTORI, 2016b). Isso se dá, inclusive, porque seus posicionamentos são, até certo ponto, bastante contraintuitivos para aqueles que estudam filosofia do Direito (SARTORI, 2015a).

Para o autor, por exemplo, longe do problema do stalinismo se colocar como uma espécie de déficit quanto ao Direito e a uma perspectiva mais "liberal", tem-se o oposto (LUKÁCS, 2015). Ou seja, para que a questão reste esclarecida, para os fins deste pequeno artigo, trata-se de ver como o marxista húngaro traz um posicionamento bastante distinto daquele que prevalece ao senso comum ao tratar do stalinismo; com isto, procurar-se-á mostrar como a crítica de Lukács ao stalinismo e ao Direito passa por uma valorização da ética em um sentido muito diferente daquele trazido pelo senso comum e pela teoria do Direito. Intentamos mostrar, ainda, como a abordagem lukacsiana distancia-se decisivamente tanto do stalinismo (e do "socialismo" do século 20) quanto do liberalismo, procurando uma perspectiva que, por meio da valorização da esfera da eticidade, procura uma "democracia socialista", "da vida cotidiana”. Não traremos, portanto, uma defesa unilateral da posição de Lukács: somente procuraremos trazer as categorias centrais pelas quais o autor trata do tema da ética para que este tema, essencial à filosofia do Direito e à teoria do Direito, possa aparecer em uma versão cuidadosa do pensamento crítico de vertente marxista.

${ }^{6}$ Colocamos entre aspas a expressão porque, tal qual Mészáros (2002), não acreditamos que o desenvolvimento soviético tenha sido essencialmente socialista. 
Acreditamos, também, que um estudo sério da obra do autor húngaro envolve a compreensão acerca da ética em seu pensamento. Pretendemos mostrar que, se a teoria do Direito contemporânea tem um aporte, sobretudo em uma teoria moral, o autor da Ontologia estabelece uma crítica a esta esfera e à esfera do Direito. Isto, como pretendemos expor, dá-se buscando apoio na problematização da esfera ética, a qual tem um significado bastante particular no autor húngaro.

No que dissemos anteriormente, tem-se um ponto bastante importante a ser destacado: se autores como Csaba Varga argumentam pela atualidade da concepção de Lukács acerca do Direito por ela supostamente se aproximar daquela de autores como Luhmann e Dworkin (VARGA, 2012), logo, de imediato, percebe-se que somente com muita dificuldade isto poderia se dar: Lukács é um crítico do Direito (SARTORI, 2010), ao mesmo tempo em que os autores mencionados não o são (SARTORI, 2015a, b). Um autor como Dworkin também não deixa de ter por central a esfera moral, e o oposto se dá em Lukács, que critica a última.

Outra questão importante passa por outro distanciamento; aquele de Lukács ante a filosofia clássica alemã: neste sentido, em um embate com a posição de Hegel e de Kant sobre o tema da moral, bem como a partir de um confronto com algumas posições específicas da filosofia do século 20, procuraremos mostrar como Lukács tenta desenvolver uma concepção materialista acerca da ética e da eticidade. Se Honneth vem a valorizar aspectos específicos da eticidade hegeliana, e se Habermas busca uma "linguistificação dos conceitos kantianos" (HABERMAS, 2002), a solução lukacsiana é outra (TERTULIAN, 2016). Neste pequeno texto, procuraremos mostrar como isto ocorre. Intentamos deixar claro que, no autor, tem-se uma crítica simultânea, colocada no campo da filosofia do Direito, à moral e ao Direito. Lukács, neste sentido, talvez possa oferecer um tertium datur, perante uma abordagem que decorra de modo mais ou menos contraditório da "teoria crítica”, quanto diante da teoria do Direito 
contemporânea; ou seja, seu aporte marxista - distinto de Pachukanis em alguns sentidos importantes - se volta tanto contra uma abordagem que tenha por central a filosofia da linguagem (a teoria do Direito) quanto contra outra, que remeta de modo mais ou menos mediado à filosofia clássica alemã (as teorias de Habermas e de Honneth).

\section{LUKÁCS CONTRA O STALINISMO: A Questão da Ética e da Democracia}

Se a abordagem lukacsiana acerca da ética se volta contra o stalinismo, podemos começar nossa análise tentando trazer alguns apontamentos, mesmo que breves, sobre o tema. ${ }^{7}$ Desde logo, percebe-se que, ao tratar do stalinismo, Lukács não enfoca na necessidade de um outro Direito ou de um Direito mais próximo ao Direito liberal. Mesmo que isto se dê em alguns de seus ex-“discípulos”, como Heller (HELLER, 1982) e como Varga - este último não deixa de elogiar autores como Dworkin (VARGA, 2012) -, Lukács marca a necessidade de um "desenvolvimento avante”, para além do Direito. Ao invés de se trazer certa "reconversão da moral em Direito", como aconteceria no stalinismo, ter-se-ia um avanço, um "avante" da moral e do Direito rumo a sua supressão (Aufhebung) na ética. A crítica lukacsiana ao stalinismo, pois, não se dá, essencialmente, com a crença em "reformas" jurídicas ou políticas e no "abrandamento do regime” como, por vezes, parece sugerir Mészáros (2002). Ou seja, o autor da Ontologia, em verdade, é muito mais crítico ao "socialismo soviético" do que normalmente se supõe (TERTULIAN, 2007b); não se tem também um apelo a uma ética como algo que expresse certa incapacidade de Lukács em tratar de "mediações políticas" (SARTORI, 2016a; PATRIOTA, 2008). Em verdade, não há “falta de mediações políticas” (MÉSZÁROS, 1972) na

${ }^{7}$ Para uma análise detida da questão, ver Tertulian (2007b). 
teoria lukacsiana - o que aparece, principalmente, em sua teorização sobre a "democracia socialista” (SARTORI, 2016a). Esta teorização, inclusive, é bastante proeminente em suas últimas entrevistas; e não só: um tema bastante espinhoso como o "fenecimento do Direito" aparece em sua Ontologia do ser social (SARTORI, 2010), bem como na forma de apontamentos, em suas Notas sobre uma ética.

Deste modo, talvez o estudo da Ontologia lukacsiana possa ser interessante para tratar de temas relevantes para a filosofia do Direito: a questão da gênese e do eventual fenecimento do Direito, ao que saibamos, conforma um tema que, tanto no positivismo quanto no pós-positivismo jurídicos, vem a ser deixado de lado. E, assim, o estudo da relação entre moral, ética e Direito talvez possa auxiliar neste campo. Ainda sobre o stalinismo, cumpre ressaltar: enquanto Lukács procura superar (aufheben) a noção de cidadão colocada na declaração de direitos do homem, paradoxalmente, no stalinismo, ter-se-ia uma valorização do Direito e do citoyen . Ter-se-ia, assim, o indício de que, em verdade, o "socialismo" soviético ainda sequer teria ultrapassado a ideologia propriamente burguesa conformada naquilo que o autor húngaro chamou de "democracia burguesa" (SARTORI, 2016a). Se é verdade que, para Lukács, "a Revolução Francesa pôs a tensão entre o citoyen e bourgeois no seio do povo livre” (LUKÁCS, 2007, p. 30), igualmente verdadeiro seria que este desenvolvimento é indissolúvel das contradições da própria sociedade regida pelo capital. ${ }^{8} \mathrm{Neste}$

\footnotetext{
${ }^{8}$ Como aponta o autor húngaro: “o ideal do citoyen das grandes revoluções [...] se fundamentou mais na transição revolucionária, nos esforços destrutivos revolucionários em relação ao feudalismo, e menos no que diz respeito ao ser social da sociedade capitalista" (LUKÁCS, 2010b, p. 282). Complementa Lukács: "estas Constituições partem da oposição-unidade entre homme (bourgeois) e citoyen. Citoyen quer dizer aqui, obviamente, o cidadão tornado "idealista", destacado de todos os vínculos materiais da existência socioeconômica; o homme, ao contrário, é aquele que faz parte da sociedade civil[-burguesa]. E Marx não esquece de observar que, neste liame indissolúvel (na medida em que todo citoyen é também homme), as Constituições revolucionárias rebaixam o cidadão à condição de servidor dos chamados direitos humanos. Com isso, elas admitem a real supremacia social do homem material, econômico, privado, sobre o cidadão ideal” (LUKÁCS, 2008, p. 89-90).
} 
sentido, a partir de Lukács talvez seja possível, com mediações, concordar com a posição de Mészáros, segundo a qual a URSS tinha como substrato real uma espécie de capital sui generis, o qual precisaria ser suprimido (MÉSZÁROS, 2002).

Nas Notas sobre uma ética, diz explicitamente o autor existir a necessidade do "domínio da ética pelo fenecimento do Direito e da Moral (fenecimentos das duas diferentes - porque supérfluos diferentemente)” (LUKÁCS, 2015, p. 69). Ou seja, faz-se necessário compreender a posição lukacsiana sobre a ética para que a dimensão de sua crítica ao stalinismo, e ao Direito, fique clara. Com isso, alguns mal-entendidos - ligados à certa tendência a aproximar o autor húngaro de uma defesa velada do stalinismo, ou, ao menos, de uma "reconciliação" com este último (LÖWY, 1998) - podem ser remediados. Ao se deixar bastante claro que a gênese da ética lukacsiana está também em uma decidida crítica ao stalinismo e a suas consequências, não há como defender um Lukács que não seja um crítico decidido de Stálin (LUKÁCS, 1972, 1969). Também pode ser esclarecido um ponto importante da posição do autor acerca do fenecimento do Direito, na medida em que o autor não confunde o fim da esfera propriamente jurídica com o fim de qualquer forma de normatividade social (e não simplesmente individual) (SARTORI, 2015a).

\section{A QUESTÃO ÉTICA DIANTE DA FILOSOFIA CLÁSSICA ALEMÃ E DA POLÍTICA}

Ainda, outro campo que aparece como central ao desenvolvimento da concepção lukacsiana de ética, diz respeito ao diálogo com a filosofia clássica alemã, notadamente com Kant e Hegel. A crítica à filosofia clássica alemã, ao Direito e à moral, pois, são aspectos importantes para o que tratamos aqui. Enquanto o autor valoriza a ética, ele critica o Direito e a moral diretamente. E aqui pretendemos mostrar - mesmo que de modo sumário - como isso foi possível ao autor húngaro. Neste sentido, uma 
outra questão importante gira em torno da diferença específica entre estas esferas do ser social (SARTORI, 2015a). Ou seja, embora reconheçamos que a questão da ética é multifacetada no pensamento do autor húngaro (a rigor, seria preciso tratar com bastante cuidado de todos estes temas que mencionamos, e de outros), pode-se trazer um ponto de partida - a oposição entre moral e ética - para a discussão destas questões. ${ }^{9}$

Acreditamos que isto seja possivel porque a oposição entre Direito, moral e ética é central ao velho Lukács (SARTORI, 2015b); assim, pode ser interessante trazer a especificidade da ética na obra do autor húngaro, explicitando a questão, diga-se de passagem, de modo oposto ao que acontece com a crítica pachukaniana ao Direito, crítica marxista mais célebre ao Direito. Nela, a moral e a ética aparecem como indiferenciadas a partir do momento em que o marxista soviético toma como ponto de partida Kant. De um viés pachukaniano, "a ética kantiana é a típica da sociedade de produção mercantil, mas, igualmente, é a mais pura e acabada da ética em geral” (PACHUKANIS, 1988, p. 131), em Lukács, tem-se o oposto. Ao mesmo tempo, em Lukács, não se aceita sem ressalvas a crítica hegeliana a Kant..$^{10}$ A questão perpassa pela relação entre a ética, a moral e a dimensão política. Há um ponto essencial para a compreensão deste aspecto, que gira em torno da ligação existente entre moral, liberalismo e decadência ideológica da burguesia (SARTORI, 2015a, b, 2016a). Lukács não tarda a apontar, neste sentido, no âmbito político, que "a ideologia liberal tapa o

\footnotetext{
${ }^{9}$ Aqui, infelizmente, não poderemos desenvolver a questão atinente ao papel da ética na ontologia lukacsiana tendo em conta seu papel ante ao estranhamento (Entfremdung), ao afastamento das barreiras naturais, bem como do modo mediante o qual o autor húngaro se coloca diante daquilo que chamou de "capitalismo manipulatório" (LUKÁCS, 1969). Basta, assim, que deixemos indicada a existência da questão para um tratamento posterior.

${ }^{10}$ No campo da ética, isso se dá, inclusive, na medida em que não deixaria de existir certo panteísmo em Hegel, enquanto este, mesmo que inconscientemente, retomaria a filosofia de Epicuro: “com essa renovação ética de Epicuro - que foi uma tendência involuntária de Hegel, historicamente inconsciente, mas nem por isso menos persistente no plano teórico - encerra-se na grande filosofia a época intermediária panteísta” (LUKÁCS, 2012, p. 209).
} 
abismo de classe da sociedade civil-burguesa através da política entendida de forma idealizada, através da moral abstrata, etc.” (LUKÁCS, 2011, p. 176).

Ou seja, ao se tratar da relação da ética com a política, o essencial a Lukács seria a crítica à ideologia liberal (que teria uma forte tonalidade moral), tendo em conta a busca pelo desenvolvimento de uma democracia específica - a democracia socialista, da vida cotidiana. Com esta última, ter-se-ia a supressão dos antagonismos classistas da sociedade civil-burguesa (bürgerliche Gesellschaft) ao suprimir (aufheben) as classes sociais (SARTORI, 2016a). No campo político, portanto, a questão da ética gira em torno do que é atinente a uma "democracia da vida cotidiana", que penetrasse na vida do homem como um todo, trazendo à consciência cotidiana o fato segundo o qual o homem é um ser autoprodutor (LUKÁCS, 2013) que, por assim dizer, faz a própria história. Neste sentido, percebe-se que o marxismo de Lukács é distinto tanto do stalinismo quanto de Pachukanis, que traz a abordagem clássica sobre o Direito e marxismo.

Declara Lukács explicitamente: "a tarefa da democracia socialista é penetrar realmente na inteira vida material de todos os homens, desde a cotidianidade até as questões mais decisivas da sociedade; é dar expressão à sua sociabilidade enquanto produto da atividade pessoal de todos os homens" (LUKÁCS, 2008, p. 117). Ou seja, há um campo importante a ser visto ao se analisar a relação entre moral e ética, aquele da política (SARTORI, 2016a). Há, no entanto, outro âmbito além do político que não pode ser esquecido e que enfocaremos aqui: o jurídico. Vale, portanto, avançar no sentido de uma análise que trate da dimensão do Direito ao se ter em conta a questão da ética (bem como da especificidade desta) e o modo concreto mediante o qual esta se coloca ao marxista húngaro. Podemos, assim, começar nosso tratamento do tema passando pela oposição 
entre moral e ética a partir da posição do autor da Ontologia sobre os dois principais expoentes da filosofia clássica alemã, Kant e Hegel. Com isso, podemos situar a questão ética em Lukács.

\section{MORAL E ÉTICA EM LUKÁCS: Uma Inflexão Diante de Kant e de Hegel}

Para que se compreenda o papel da ética na obra lukacsiana, deve-se esclarecer que ela não é retomada por Lukács como algo que possa dar um desenvolvimento aos seus anseios juvenis por uma moral comunista, a ser procurada em oposição ao tratamento hegeliano da "eticidade" (Sittlichkeit). ${ }^{11}$ Lukács afirmava, em 1919, momento de transição em sua formação intelectual, ${ }^{12}$ que "Hegel não tem ética alguma; nele, a ética é suplantada pelo sistema dos bens materiais, intelectuais e sociais nos quais culmina sua filosofia social" (LUKÁCS, 2005, p. 30). Em Tática e ética, justamente este aspecto é visto com diversas ressalvas, e a eticidade hegeliana é enxergada enquanto uma esfera que, erroneamente, sai do campo da moral e caminha rumo a uma "filosofia social”. Nesta última, vir-se-ia a tratar dos "bens materiais, intelectuais e sociais" que estão presentes no desenvolvimento do espírito objetivo e que aparecem nas figuras da família, da sociedade civil-burguesa e do Estado. A tônica da crítica lukacsiana a Hegel, portanto, estava centrada em uma crítica ao caráter concreto da

\footnotetext{
${ }^{11}$ É importante destacar que Lukács critica uma de suas grandes obras de "juventude" do seguinte modo: "a teoria do romance, até aonde posso enxergar, é o primeiro livro alemão em que uma ética de esquerda, norteada pela revolução radical, aparece alinhada com uma exegese tradicional da realidade" (LUKÁCS, 2000, p. 17-18). E complementa: "em resumo, o autor da Teoria do romance possuía uma concepção de mundo voltada para a fusão de uma ética ‘de esquerda' e epistemologia ‘de direita' (ontologia, etc.)” (LUKÁCS, 2000, p. 17). Deve-se notar na passagem que Lukács é essencialmente crítico quanto a sua obra "juvenil"; em verdade, de suas críticas a estas obras, de certo modo, surge a necessidade de uma tematização mais cuidadosa e, essencialmente, materialista, da questão da ética.

${ }^{12}$ Para uma análise rigorosa da evolução do pensamento de Lukács, ver VAISMAN; FORTES, 2010.
} 
eticidade em oposição à valorização da moral, da "moralidade" (Moralität), que perpassaria um ímpeto revolucionário. Para nossos presentes propósitos, é importante destacar: a posição de Lukács em sua obra madura é, até certo ponto, a oposta.

Justamente, vem o autor a destacar aquilo que criticou anteriormente: a posição da moralidade ante a eticidade no sistema hegeliano. Ele não deixa de ter por central o estudo detido da atividade humana (TERTULIAN, 2010, 2007a, b), e, com ela, do momento de dever (Sollen) na práxis social (ANDRADE, 2016); e desenvolve a questão ao tratar da heterogeneidade das esferas do ser social, procurando traçar a relação existente entre os indivíduos concretos que trazem certas ponderações, por assim dizer, morais, diante da conformação real e efetiva de sua atividade social. Esta última seria algo mediado por complexos sociais parciais (SARTORI, 2010) que conformam a eticidade. Neste sentido, embora a moralidade - ligada à valoração, presente na atividade social (LUKÁCS, 2013) - seja parte do percurso constitutivo da objetividade social, ela caminharia à eticidade. $\mathrm{O}$ que ressalta o marxista húngaro em sua Ontologia acerca da relação entre moralidade e eticidade em Hegel, pode ser elucidativo sobre este ponto:

Para Hegel, [...] a inteira moralidade é tão somente uma parte da práxis humana que encaminha para a autêntica eticidade. E o dever-ser tem um significado real apenas enquanto expressa a defasagem entre a vontade humana e "o que é em-si". Na eticidade, essa defasagem é superada e, por conseguinte, o posto central do dever-ser é eliminado também no mundo da práxis. A profunda correção e a igualmente profunda problematicidade dessa posição só poderão ser adequadamente discutida na Ética ${ }^{13}$ (LUKÁCS, 2012, p. 189).

\footnotetext{
${ }^{13}$ Para Lukács, a esfera da ética vem a ser decisiva na discussão sobre questões decisivas, as quais pressupõem o "afastamento das barreiras naturais", mas não se reduz a ele: "não esquecermos que os âmbitos de possibilidades assim criados se tornaram indispensáveis para a auto-reprodução dos seres humanos em uma sociedade sociabilizada (e evidentemente também para a auto-reprodução desta última). A verdadeira descrição dessas ques-
} 
Se em 1919 Lukács critica o modo mediante o qual Hegel leva em consideração a moralidade, uma vez que o autor alemão a considera "somente" como um momento anterior à eticidade, na Ontologia, se tem uma antítese direta. A moralidade não é ignorada pelo autor da Fenomenologia do espírito, claro; Lukács também não a ignora e a relaciona com a valoração (ANDRADE, 2016). O tratamento da questão, todavia, é bastante distinto diante da Tática e ética: na Ontologia; a moralidade é "uma parte da práxis humana”, sendo justamente a anatomia desta atividade, cujo modelo, protoforma, está no trabalho, o central. A moral é parte importante no percurso de conformação da eticidade, até mesmo porque, sempre, a valoração tem por base real atributos e determinações do próprio real, conformados em valores de uso (LUKÁCS, 2013; ANDRADE, 2016). Neste sentido, mesmo para tratar da questão da "moralidade", a ontologia lukacsiana não pode ser deixada de lado em um estudo detido do ser social e de seus atributos. A crítica lukacsiana à moralidade, colocada essencialmente em sua figura kantiana - mas o mesmo seria válido para outras formas desta (SARTORI, 2015a) - está centrada, sobretudo, em certa hipostasia do dever-ser (Sollen) (SARTORI, 2010). Novamente: o autor húngaro não desconsidera o papel do dever-ser; no entanto, ligando-o à atividade humana, coloca-o enquanto um momento da realização de um télos na objetividade mesma; télos este que passa a ter por central nexos reais e efetivos que se conformam enquanto uma forma de causalidade posta (LUKÁCS, 2013). O dever-ser, pois, não está colocado em um momento autônomo, que daria base a algo como a moral, concebida enquanto um âmbito igualmente autônomo da sociabilidade. Esta, acredita Lukács, é, até certo ponto, a posição de Kant; segundo o marxista húngaro, por outro lado "o dever-ser tem um significado real apenas enquanto

tões vai muito além dos quadros de uma introdução, necessariamente geral, pois pertence a uma análise concreto-sistemática da constituição do ser das atividades humanas, da práxis cotidiana até a ética mais elevada” (LUKÁCS, 2010a, p. 221-222). 
expressa a defasagem entre a vontade humana e 'o que é em-si'”. Ou seja, o dever, por meio do pôr teleológico da atividade humana, é um elo mediador entre a conformação objetiva da realidade efetiva (Wirklichkeit) - também marcada por nexos colocados pelo próprio homem em meio ao processo de afastamento das barreiras naturais - e a subjetividade, no caso, amparada na vontade. A “defasagem” entre "o que é em-si” - e que, portanto, tem uma existência independente da consciência até certo ponto - e a vontade humana tem a moral como elo intermediário na conformação das instituições sociais e dos hábitos a elas ligados (e trazidos na eticidade). Isto é, a categoria do dever-ser, para Lukács, somente poderia ser tratada na medida em que ela é um momento da conformação de uma finalidade, enquanto uma causalidade posta na realidade efetiva. Assim, tem-se: qualquer muralha chinesa entre ser (Sein) e dever-ser está vedada. Tratar da moral é compreender o seu locus no ser social, tendo-se sua relação com a eticidade como algo central e que pode ser analisado ao se ter em mente a complexidade da atividade social.

Este, ao fim, seria o locus da moral, essencialmente ligada à elaboração de uma prévia ideação e, também, de uma prescrição: trata-se, pois, de um elo intermediário colocado ao indivíduo na valoração acerca dos meios e dos fins de sua atividade real e efetiva (SARTORI, 2010).

Assim, pode-se afirmar que, em Lukács, embora a moral seja um elo no modo mediante o qual o homem traz distintas objetivações (Vergegenständlichung), ela nunca seria o "central”. O elogio lukacsiano a Hegel, pois, traz a superioridade da eticidade perante a moralidade na medida em que se retira de campo um suposto "posto central do dever-ser", e enfatiza o ser-propriamente-assim da efetividade. A partir do momento em que este "posto" deixa de ser visto enquanto algo hipostasiado (como ocorreria, em grande parte, em Kant), tem-se, de acordo com o autor húngaro, que sua realização encontra-se justamente em razão daquilo “que é em-si” e que se 
conforma na realidade efetiva. ${ }^{14} \mathrm{Ou}$ seja, o critério para que se compreenda a natureza de qualquer "dever-ser" deixa de estar naquilo que os sujeitos pensam de si mesmos e passa para a sua real e efetiva conformação no mundo objetivo (LUKÁCS, 2010a). A “centralidade do dever-ser”, assim, é retirada de campo por Lukács ao se ter a superação real e efetiva, mediante a atividade humana concreta, da "defasagem" entre vontade e "o que é em si”. Isto, segundo o marxista húngaro, ocorre em um duplo sentido: no plano teórico, a concepção lukacsiana procura justamente trazer à tona a complexidade da práxis humana ao enfatizar a correlação dos momentos subjetivos e objetivos da práxis social; já no plano prático, tem-se que a realidade efetiva mesma é - até certo ponto ${ }^{15}$ - um fruto da atividade humana. Isto se dá de tal modo que, não obstante a dependência da práxis diante de um posicionamento valorativo do sujeito ante a realidade, o produto desta atividade passa a possuir uma existência autônoma, a qual nem sempre corresponde àquilo que foi planejado pelo sujeito.

Assim, a superioridade da eticidade perante a moralidade expressa também o materialismo de Lukács. Isto se apresenta na medida em que o produto social da atividade humana passa a ter uma existência autárquica diante daquele que a produz. Para Lukács, “o posto central do dever-ser é eliminado também no mundo da práxis” na medida em que se passa a julgar os homens e uma época pelo que são, e não pelo que eventualmente

\footnotetext{
${ }^{14}$ Como aponta Lukács: "em sua essência mais íntima, todo o âmbito da atividade do ser humano é determinado pela realidade existente em si, ou seja, pelo seu espelhamento na consciência predominante em cada época: essas concepções atuam sobre os diversos conteúdos e formas da práxis humana. Esse complexo só pode receber um tratamento adequado e aprofundado no âmbito das ciências sociais concretas, nas análises concretas da práxis humana, incluída a ética" (LUKÁCS, 2012, p. 74-75).

${ }^{15}$ Esta ressalva é importante porque, ao contrário do que acontece em História e consciência de classe, Lukács não se cansa de destacar, em sua obra madura, que há sempre um elemento "natural" ineliminável na realidade efetiva. Ter-se-ia sempre o "afastamento das barreiras naturais, mas nunca sua supressão. Neste sentido, a realidade efetiva não é somente fruto da atividade humana, mas também das condições materiais legadas pelo passado para que esta possa se dar.
} 
vêm a dizer de si mesmos. Não obstante a importância - por vezes decisiva - da valoração moral, esta teria como critério as potencialidades e possibilidades (Möglichkeiten) presentes na própria realidade efetiva: ou seja, a valoração é parte do processo pelo qual são produzidos produtos sociais de tal modo que se trata de enxergar a maneira concreta mediante a qual se tem a passagem da valoração para a objetivação de entes (Seienden) materiais ou espirituais. ${ }^{16}$ Este seria, para o autor da Ontologia, o verdadeiro âmbito do tratamento da eticidade, aquele em que se afirma a primazia da realidade efetiva ante a consciência.

Ao acompanharmos o raciocínio do autor húngaro, percebe-se: a eticidade tem essa existência bastante concreta. Sua superioridade diante da moral traz também um ímpeto materialista bastante destacado. Ou seja, o elemento que era criticado em Hegel anteriormente, em 1919, agora, de modo bastante mediado, passa a ser elogiado. Tem-se um elogio ao "realismo" do autor alemão, não obstante este ímpeto de Hegel se colocar de modo bastante problemático. ${ }^{17}$ Lukács não deixou de apontar também como isto, no autor da Fenomenologia, veio acompanhado de um elemento fortemente teleológico colocado na figura da “astúcia da razão”, e que não deixou de expressar de modo bastante problemático a uma mistificação da esfera da eticidade e de seu percurso (LUKÁCS, 2013, 1963)..$^{18}$

\footnotetext{
${ }^{16} \mathrm{~A}$ problemática é tratada com muito cuidado tanto na Ontologia quanto na Estética de Lukács, trazendo-se, no caso da última obra mencionada, um destaque todo especial para a objetivação de entes com uma existência espiritual.

${ }^{17}$ Sobre a categoria da reconciliação (Vörsonung), comenta Lukács: “esta reconciliação é, por um lado, uma mistificação idealista de contradições irresolúveis; mas, por outro lado, ela expressa ao mesmo tempo o sentido realista de Hegel, sua proximidade da realidade social concreta de sua época, seu profundo conhecimento da vida real da sociedade humana, seus esforços de descobrir as contradições do progresso no seu verdadeiro campo de batalha que está na vida econômica do homem” (LUKÁCS, 1963, p. 413).

${ }^{18}$ Lukács aponta uma tendência panteísta em Hegel, sendo isto central para a crítica a sua noção de eticidade: "com essa renovação ética de Epicuro - que foi uma tendência involuntária de Hegel, historicamente inconsciente, mas nem por isso menos persistente no plano teórico - encerra-se na grande filosofia a época intermediária panteísta" (LUKÁCS, 2012, p. 209). Para o papel de Epicuro, aponta Lukács: “o jovem Marx vê com toda a clareza
} 
A dubiedade de Hegel, assim, estaria, tal qual no caso da categoria da reconciliação (Vörsonung) (LUKÁCS, 1963), em sua "profunda correção e a igualmente profunda problematicidade”, a qual, no limite, viria a trazer certa elevação ao patamar de razão - figuras econômicas tratadas por Smith, Ricardo e outros autores da economia política. E estes são autores contra os quais a obra marxiana se dirige..$^{19}$ Juntamente com um erro “filosófico" (a logicização do real (LUKÁCS, 2013)), ter-se-ia um erro de análise de realidade. A partir da "posição da economia política" (LOPES, 2010), vem-se a enxergar a sociedade civil-burguesa como o cume insuperável e insuprimível do processo de desenvolvimento humano.

Segundo Lukács, o tratamento hegeliano da eticidade, pois, pressupõe uma valorização positiva acerca do capital, mesmo que o autor não deixe de ter críticas ao "espetáculo de devassidão bem como o da corrupção e da miséria” (HEGEL, 2003, p. 169), conformado na sociedade civil-burguesa (SARTORI, 2014). A eticidade hegeliana estaria marcada por certa cegueira diante das reais e efetivas potencialidades da resolução do antagonismo entre sociedade capitalista e Estado.

Ou seja, percebe-se que a questão da ética é essencial para Lukács na medida em que se tem, na conformação do complexo social, ao menos, um duplo fronte: de um lado a moral, que, em sua melhor expressão, é

a universalidade do atomismo de Epicuro. E assume a tarefa de não apenas esclarecer a gênese e o funcionamento da matéria no sentido mais estrito, mas de descrevê-los como princípio fundador abrangente de todo o ser, que nele culmina na ética” (LUKÁCS, 2010a, p. 132). Sobre a influência de Epicuro em Marx, ver Albinati (2005).

${ }^{19}$ Segundo Lukács, “o jovem Hegel estudou economia na obra do inglês James Steuart; conhecemos apenas os títulos de seu comentário, escrito em 1799. [...] Conhecemos bem mais os manuscritos sobre economia que escreveu em Iena. Sabemos que ele estudou atentamente Adam Smith" (LUKÁCS, 2007, p. 92). Depois, aponta algo essencial no que diz respeito ao tema aqui estudado, quando afirma que fora essencial para a filosofia de Hegel "o aproveitamento econômico, social e filosófico da concepção de trabalho tomada de Smith” (LUKÁCS, 1963, p. 321). Um autor como Franz Rosenweg, insuspeito quanto a eventuais simpatias marxistas, também destaca o seguinte: "a vida econômica - sistema de necessidades - é revista por Hegel com os olhos da economia política ocidental: ele cita elogiosamente Smith-Say-Ricardo” (ROSENZWEIG, 2008, p. 452). 
tratada em Kant; doutro lado, a eticidade, que é trazida à tona na crítica à concepção hegeliana, a qual seria simultaneamente profunda e problemática. A conformação concreta da eticidade, pois, aparece enquanto o autor húngaro elogia o tratamento hegeliano da questão e o critica, de modo decidido, ao mesmo tempo. Com isso, tem-se, em Lukács, e em oposição a Kant e Hegel, a valorização do tratamento marxiano da relação estabelecida entre sociedade civil-burguesa e Estado (temática tratada por Hegel em meio à eticidade). Busca o autor húngaro criticar Hegel porque, segundo Lukács, no autor da Fenomenologia, "a relação entre sociedade civil-burguesa e Estado burguês é entendida, de modo unilateral e mecânico, com a absoluta supremacia ideal do Estado" (LUKÁCS, 1979, p. 24). A questão da ética em Lukács, pois, pode ser essencial também para que seja possível esclarecer mediações que possam contribuir, inclusive, na compreensão da posição do autor diante da necessidade de supressão tanto da sociedade civil-burguesa quanto do Estado. Neste sentido, até certo ponto, a questão - tratada noutro lugar (SARTORI, 2016a) - acerca da crítica lukacsiana à democracia burguesa e ao liberalismo, pode ser vista como uma questão, também, por assim dizer, ética.

A questão ética, no autor da Ontologia, é aquela do "que fazer?" diante da conformação real e efetiva da sociedade. Mesmo que o autor não remeta a todo o momento a este complexo social, ao que parece ele poderia ser central no desenvolvimento de sua obra. Isto se dá também porque o modo mediante o qual os dilemas do presente poderiam ser tratados com cuidado em meio à apreensão das determinações objetivas da efetividade, remeteria à ética.

No que respeita este escrito, trata-se somente de enxergar a posição concreta da ética diante de outra instituição que se coloca na eticidade - aquela do Direito. Trata-se de procurar enxergar, na obra lukacsiana, a relação entre Direito e ética para que, com isso, possa se abrir uma perspectiva marxista, crítica e reflexiva no campo da filosofia do Direito. 


\section{6 ÉTICA, ONTOLOGIA E A QUESTÃO DO “QUE FAZER" EM LUKÁCS}

Pelo que dissemos, em Lukács a ética tem um maior grau de concretude se comparada à moral, de modo que a última se configura justamente como um elo intermediário na conformação real e efetiva da eticidade. A centralidade a ser trazida à ética por Lukács, assim, traz à tona seu materialismo e, o que é correlato, a prioridade da efetividade diante do dever. ${ }^{20}$ Neste sentido, se é verdade que a discussão sobre a relação entre moral e Direito é bastante forte na teoria do Direito e na filosofia do Direito (MACEDO, 2011), ao seguir as indicações de Lukács talvez fosse preciso adotar uma posição que - no campo da compreensão crítica do fenômeno jurídico - se voltasse mais à ética que à moral. Isto se dá porque a moral é tratada pelo autor ao se relacionar com aquilo sobre o qual desenvolveu críticas decididas: o liberalismo e a conformação do Direito na sociedade capitalista (SARTORI, 2015a, b); a ética, por outro lado, embora se relacione sempre com a conformação objetiva do ser social - "nenhuma ética sem ontologia” (LUKÁCS, 2015, p. 181) 21 -, segundo o marxista húngaro, em um duplo sentido, tem maiores potencialidades que a moral. Em primeiro lugar, isso se dá porque a questão acerca do dever-ser é vista na esfera sem qualquer espécie de hipostasia, tendo-se em conta a relação imbrincada entre a conformação objetiva do ser social, das instituições sociais e as limitações destas instituições (como o Direito, por exemplo); em segundo lugar, porém, tem-se o mais importante: ao se

\footnotetext{
${ }^{20}$ Para um tratamento cuidadoso desta prioridade, ver Tertulian (2016).

${ }^{21}$ Para o conceito de ontologia em Lukács, ver Sartori (2016b). É importante lembrar aquilo que destaca José Paulo Netto: “ao avançar para a construção da sua Ética, Lukács foi levado a reconhecer que haveria de fundá-la expressamente - pretendendo uma formulação histórico-sistemática efetivamente materialista e dialética, rigorosamente fiel à inspiração de Marx - na especificidade do ser social. Havia, portanto, de estabelecer, em primeiro lugar, a determinação histórico-concreta do modo de ser e de reproduzir-se do ser social. Vale dizer: sem uma teoria do ser (uma ontologia) social, a ética seria insustentável (enquanto uma ética materialista e dialética)" (NETTO, 2012, p. 16).
} 
ter em mente a apreensão do "ser-propriamente-assim" (Geradesosein) da própria sociedade - o que só seria possível ao considerar a eticidade enquanto elemento superior à moralidade segundo o autor da Ontologia -, a esfera da ética traria consigo uma problemática que gira em torno da possibilidade de questionamento da própria constituição objetiva da sociabilidade presente.

A ética conforma-se enquanto um complexo social que, neste sentido, passa pela atividade humana na medida em que também poderia ser um elo mediador importante entre a teorização sobre o presente e a práxis que buscasse a superação do mesmo. Como aponta Lukács, “os problemas ontológicos não possuem apenas um caráter puramente teórico, ainda que, naturalmente, a correção teórica seja decisiva para sua extensão à prática, à ética” (LUKÁCS, 2012, p. 104).

Neste sentido, seria preciso analisar com cuidado o modo mediante o qual se tem uma relação entre a "correção teórica" e "a prática, a ética”. Neste percurso, haveria, inclusive, a mediação real e efetiva de termos intermediários; eles perpassam o modo mediante o qual a vida cotidiana está marcada pelo hábito, pela tradição e pela educação (considerados em um sentido amplo) de tal maneira que a ética, em grande parte, na obra lukacsiana, poderia se colocar como uma esfera em que estas relações complexas são compreendidas a partir de uma ontologia do ser social ("nenhuma ética sem ontologia"). Com isso, aponta o marxista húngaro algo que poderia ser visto como um equívoco por Pachukanis (1988), mas que remete à relação entre o Direito e a ética, a qual, embora malvista pelo autor soviético, é central ao húngaro (SARTORI, 2015b): "Um sistema jurídico não pode funcionar muito tempo se não tem nada a ver com as concepções éticas de um povo. A afirmação oposta parte de uma abstração conceitual e historicamente falsa” (LUKÁCS, 1966, p. 220). 
A relação entre as "concepções éticas de um povo" e o "funcionamento" de um "sistema jurídico” vem a ser destacada por Lukács em oposição à relação entre moral e Direito. $\mathrm{O}$ autor destaca esta última, principalmente, levando em conta o funcionamento interno e, segundo ele, manipulatório da esfera jurídica (SARTORI, 2015a, b). Novamente, o autor dá algum destaque à questão moral, não negligenciando a especificidade de cada esfera do ser social; no entanto, ao trazer a diferenciação entre moral e ética como importante, distinção esta ausente na tradição marxista de crítica ao Direito, escapa daquilo que Pachukanis critica (SARTORI, 2015a), no caso, o tom lukacsiano é claramente crítico à moral, inclusive, no que respeita à relação existente entre a conformação política do presente, mormente marcada pelo liberalismo e por figuras políticas a ele relacionadas de modo mais ou menos mediado, e certa centralidade da moral na sociedade civil-burguesa (SARTORI, 2016a). Ou seja, enquanto a moral pode ser importante para compreender a atividade - em grande parte marcada por uma dose de autoengano - do próprio jurista, segundo o autor húngaro isto não basta em um tratamento cuidadoso do complexo jurídico.

O Direito mesmo, em sua função social, envolve os hábitos, tradições e a institucionalização de formas específicas de vida e de sociabilidade, nas quais os homens se relacionam real e efetivamente em meio àquilo que Hegel chamou de eticidade. Elas, portanto, somente podem ser julgadas tendo em conta a efetividade do ser social, e não as justificativas morais, por mais elaboradas que sejam, da jurisdição jurídica. Isto é, para Lukács, trata-se sempre de enxergar a relação existente entre hábitos e tradições corporificadas contraditoriamente nas instituições sociais que compõem o percurso que conforma a eticidade. Esta última, por sua vez, ao levarmos em conta a problematização hegeliana, vai da família ao Estado, passando pela sociedade civil-burguesa; para Lukács, o âmbito em que o Direito pode ser visto, portanto, não é tanto aquele da moralidade, mas o da eticidade. Até certo ponto, este é o sentido em que, segundo o mar- 
xista húngaro, as "concepções éticas de um povo" dão base ao "sistema jurídico”. Trata-se, deste modo, de considerar com cuidado a relação entre a questão do "que fazer"22 e a subordinação da moral à realidade efetiva do ser social e dos complexos sociais que o compõem. Com isso, e desta forma, tem-se a possibilidade de relacionar os "problemas ontológicos" real e efetivamente "à prática, à ética."

Ao tratar da esfera ética, Lukács procura fornecer fundamentos sólidos para que seja possível se responder à questão do “que fazer" diante da conformação objetiva do capitalismo de sua época, que chamou de “capitalismo manipulatório" (SARTORI, 2016b), analisando com cuidado a esfera da ética, pois, segundo Lukács, aborda-se a atividade concreta do homem em meio às contradições que marcam a reprodução do ser social da sociedade. Elas se expressam em meio a complexos sociais parciais específicos (como o Direito e a política, por exemplo), que possuem maiores ou menores possibilidades diante da efetividade. Por mais que, por vezes, uma sociabilidade específica pareça se acoplar aos homens como uma espécie de "segunda natureza”, segundo o autor húngaro, trata-se de ver o modo concreto mediante o qual esta aparência pode ser rompida em meio à atividade concreta dos homens. A esfera ética poderia ajudar nisto.

Neste ponto, é importante destacar a importância da temática, dado que, também segundo Marx (autor que Lukács procura resgatar diante da leitura stalinista e marxista vulgar), ${ }^{23}$ "no evolver da produção capitalista

\footnotetext{
${ }^{22}$ Ao tratar de Heidegger, criticando-o (SARTORI, 2012), Lukács levanta a relação entre a questão do "que fazer?" e a ética: “o contraste, tão importante para a influência exercida por Heidegger, entre autenticidade e inautenticidade do ser humano num mundo manipulado por 'o impessoal [das Man]' é, no fundo, uma questão ética que, também no caso dele, como veremos mais adiante, necessariamente terminará numa das alternativas oferecidas pela pergunta "que fazer?” (LUKÁCS, 2012, p. 91).

${ }^{23}$ Ao tratar da relação entre a determinação econômica e o Direito, Lukács assevera o seguinte: "nessa questão, o marxismo vulgar não foi além da declaração de uma dependência niveladora, mecânica, em relação à infraestrutura econômica (o neokantismo e o positivismo do período revisionista representaram um castigo justo da história por essa
} 
desenvolve-se uma classe de trabalhadores que, por educação, tradição e hábito, reconhece as exigências desse modo de produção como leis naturais e evidentes por si mesmas" (MARX, 2013, p. 808). Justamente em meio àquilo que Hegel chamou de eticidade, tem-se o reconhecimento (Annerkenung) das exigências do modo de produção capitalista por meio da “educação, tradição e hábito”, de tal modo que estes passam a conformar peças importantes na reprodução do ser social do capital (SARTORI, 2010; ANDRADE, 2016). Ou seja, os elos intermediários na conformação das instituições sociais passam a fazer parte da problemática marxiana, de tal modo que a eticidade hegeliana passa a ser vista de forma a se apreender a especificidade de cada esfera do ser social com maior cuidado: ao contrário do autor da Fenomenologia, segundo Lukács, não se trata de considerar os complexos sociais, essencialmente, em meio ao desenvolvimento teleológico do espírito (LUKÁCS, 2013), mas, sim, de apreender a especificidade de cada complexo. Neste percurso, buscar-se-ia deixar clara a relação existente entre os elementos que compõem o preparo da atividade social e a objetividade das instituições e do ser social em meio ao qual esta atividade é realizada. Na relação concreta que perpassa o "envolver da produção capitalista” tem-se a formação objetiva dos trabalhadores em meio ao hábito, à educação e à tradição, de tal forma que, já em Marx, há uma relação íntima entre estas figuras e certa naturalização da produção capitalista que estava, à época, se colocando sobre os próprios pés.

No modo de produção capitalista, certamente, de acordo com o autor da Ontologia, de uma maneira bastante mediada, "as concepções éticas de um povo" dão fundamento ao funcionamento de "um sistema

vulgarização). O período stalinista, por sua vez, exacerbou novamente essa concepção mecanicista e a transpôs para a práxis social pela força; os resultados são conhecidos de todos” (LUKÁCS, 2013, p. 249). Para real superação de qualquer mecanicismo quanto à determinação econômica do Direito, acreditamos, é bastante importante tratar da relação entre Direito e cotidiano (SARTORI, 2010); porém, é também de grande relevo averiguar a heterogeneidade - e relação - entre Direito, moral e ética. É neste sentido que este artigo pretende se colocar em meio à temática. 
jurídico" na medida em que tende a haver certa aceitação, mediada pelo reconhecimento das "exigências desse modo de produção". Elas, ao fim, passam a ser aceitas como "leis naturais e evidentes por si mesmas", e o Direito, segundo Lukács, tem uma função bastante destacada nisto, certamente (SARTORI, 2010). A questão, no entanto, é mais meandrada.

Marx destaca o modo em que surge e "desenvolve-se uma classe de trabalhadores” específica, de tal feita que, em verdade, há dois pontos a se destacar: primeiramente, não se tem somente esta classe específica de trabalhadores em meio ao desenvolvimento multifacetado do capitalismo; em segundo lugar, como mostra Marx em $O$ capital, não há qualquer necessidade absoluta de o trabalhador permanecer submisso à valorização do capital. Justamente, a partir dos seus próprios "hábitos, tradições e educação”, eles podem voltar-se contra a conformação objetiva da sociedade civil-burguesa Destaca-se que a ética, segundo Lukács, não está simplesmente acoplada ao modo de produção capitalista; sua especificidade mesma é trazida à tona na medida em que seria possível questionar esta forma de sociabilidade. Ela, relacionada a uma ontologia do ser social, estuda justamente os elos intermediários entre a subordinação à sociabilidade presente, a contraposição a esta sociabilidade e a possibilidade de supressão da mesma.

Minha atividade essencial depois de 1956 está ligada a estas tarefas. As obras maiores, uma recém-concluída Ontologie des gesellschaftlichen Seins (Ontologia do ser social) e uma projetada Ética pretendem oferecer contribuições para a fundamentação de uma práxis comunista no presente ... e no futuro (LUKÁCS, 2008, p. 212).

É certo que Lukács não discorre somente de sua Ética. As passagens citadas, no entanto, deixam clara a ligação da Ontologia com a "projetada Ética" do autor. Na obra "recém-concluída”, o autor húngaro trata das "bases da atividade humana", e essas bases mesmas seriam imprescindíveis para que se pudesse tratar das formas mais elaboradas de ati- 
vidade prática, as quais seriam tratadas justamente no âmbito da ética. ${ }^{24}$ Para o que nos diz respeito neste momento, devemos apontar somente que, se a atividade humana não é inelutavelmente estranhada, a dimensão ética, segundo Lukács, poderia ser bastante importante. ${ }^{25}$ Novamente, se o estranhamento é essencialmente uma categoria social (LUKÁCS, 2013; SARTORI, 2012), trata-se justamente de averiguar as mediações sociais que o tornam possível e, em certo sentido, necessário, em meio à reprodução social de determinadas formações sociais. Assim, seria "de uma abstração conceitual e historicamente falsa” deixar de perceber que "as concepções éticas de um povo" não são necessariamente funcionais ao funcionamento do Direito positivo. Por mais que “educação, tradição e hábito" possam trazer certo reconhecimento das bases do modo de produção capitalista, este reconhecimento não necessariamente traria a aceitação acrítica de determinada conformação objetiva da sociabilidade: segundo Lukács, justamente a especificidade da atividade ética se encontraria na possibilidade (e não na necessidade absoluta) de romper com o processo de obscurecimento - mediado pelo estranhamento (Entfremdung), em ver-

\footnotetext{
${ }^{24}$ Expõe Lukács nos Prolegômenos algo que deixa clara a relação que apontamos, em que, simultaneamente, o desenvolvimento de uma ética depende de uma ontologia do ser social, em que as bases da atividade humana sejam tratadas por meio do processo de afastamento das barreiras naturais e em que, passando pela problematização da vida cotidiana, chega-se à esfera, por assim dizer, "mais elevada" da atividade social : "quanto mais os próprios seres humanos se tornam objetos de atividades humanas, tanto menos essa generalidade se mantém como tal, tanto mais importante nela se torna o momento de uma relativização no processo, a esse propósito; a homogeneização assume o caráter de uma mera aproximação geral. Os problemas categoriais que assim surgem constituem momentos importantes da caracterização adequada da atividade humana. Seu campo de realização estende-se do trabalho, da vida cotidiana, até as formas mais elevadas de atividade, na ética” (LUKÁCS, 2010, p. 225).

${ }^{25}$ Este seria o equívoco de grande parte da filosofia burguesa, segundo Lukács: "para a crítica filosófico-burguesa da civilização - basta pensar em Heidegger -, era muito óbvio sublimar a crítica social numa crítica puramente filosófica, fazer do estranhamento, social em sua essência, uma conditione humaine eterna, para utilizar o termo que surgirá só mais tarde" (LUKÁCS, 2003, p. 26). Aqui, modificamos a tradução de alienação por estranhamento para que o texto fique coerente. Não entraremos, porém, na polêmica sobre a questão da tradução do termo Entfremdung.
} 
dade, pelas diversas formas de estranhamento (ALCÂNTARA, 2014) - do hábito engendrado no capitalismo. Em meio ao processo mediante o qual se "reconhece as exigências desse modo de produção como leis naturais e evidentes por si mesmas”, não haveria qualquer necessidade absoluta. A ética buscaria a real fundamentação de uma "práxis comunista no presente... e no futuro", na medida em que a questão do "que fazer" remete à possibilidade de uma passagem para além da sociedade capitalista e, para que se use a dicção de Mészáros, "para além do capital” (MÉSZÁROS, 2002).

De acordo com Lukács, a questão da ética, portanto, não só não remete a uma "falta de mediações políticas" na teoria lukacsiana; ela leva para a análise cuidadosa da questão.

Para o autor da Ontologia, o socialismo teria justamente este sentido, o qual deveria ser perpassado pela ética ao tratar das diversas mediações sociais em meio a uma práxis que trouxesse consigo uma forte posição contra qualquer tipo de potência estranhada: "socialismo: recuo do estranhamento $^{26}$ (Entfremdung) pela extensão da objetivação - lugar d. Ética” (LUKÁCS, 2015, p. 63). Tratar da relação entre ética e Direito, pois, significa passar pelo modo mediante o qual a ética, segundo Lukács, traria a possibilidade de uma oposição ao reconhecimento das "exigências desse modo de produção como leis naturais e evidentes por si mesmas”. Ou seja, trata-se de buscar formas de objetivação que se oponham ao estranhamento social vigente sob o domínio do capital. Por mais que a palavra não seja central a Lukács, pode-se afirmar que, em verdade, tem-se, portanto, a oposição à determinada conformação específica da “eticidade”, aquela da sociedade capitalista.

${ }^{26}$ Aqui, modificamos a tradução de alienação por estranhamento pelas mesmas razões. 
Tratar-se-ia, sempre, de "oferecer contribuições para a fundamentação de uma práxis comunista no presente... e no futuro”, para que fosse possível se opor às potências estranhadas colocadas pelo capital. A ética, em Lukács, tem como questão central a oposição, por meio da atividade concreta do homem, às diversas formas de estranhamento; a tematização ética é aquela que diz respeito à supressão de uma forma de sociabilidade, em que a seguinte situação se perpetua: “em certo sentido se poderia dizer que toda a história da humanidade, a partir de um determinado nível da divisão do trabalho (talvez já daquela da escravidão), é também a história da alienação humana” (LUKÁCS, 1981, p. 569). Para Lukács, em meio a isso a moral e o Direito, em mútua confluência, viriam a reforçar estas potências estranhadas, sendo funcionais ao desenvolvimento desigual e contraditório do capital. Antes de moral e Direito poderem contribuir para uma democracia socialista, ter-se-ia o oposto, sendo necessário remeter à questão ética do "que fazer".

A relação entre moral e ética, neste sentido, traz a questão da especificidade e da potencialidade das esferas distintas do ser social diante da tarefa - valorizada no marxismo - da supressão do capital e, com ele, das potências estranhadas colocadas sobre sua base; trata-se, portanto, de enxergar as potencialidades e possibilidades que cada complexo social diante da conformação objetiva da totalidade social. Ao se ter em conta a relação básica da conformação do ser social, pode-se ressaltar que uma ética marxista traria o reconhecimento da simultânea dependência e autonomia relativa do ser social ante o natural, bem como dos nexos objetivos presentes na própria sociabilidade de determinada época - trata-se da questão do "afastamento das barreiras naturais". ${ }^{27}$ Em meio a isto, tem-se

\footnotetext{
${ }^{27}$ Segundo o autor, “o desenvolvimento (inclusive a passagem a um nível superior) nada tem a ver com a sua avaliação - em sentido ético, cultural, estético, etc. As avaliações desse tipo surgem, com necessidade ontológica, no quadro e no decurso do ser social; e será uma tarefa específica importante determinar com precisão a sua relevância ontológica, ou seja,
} 
também a conformação dos complexos distintos como determinações reflexivas, simultaneamente, dependentes entre si e dotados de uma autonomia relativa que remete as suas determinações reais e efetivas. Diante da problematização ética, a "legalidade" própria da objetividade (Gegenstandlichkeit) seria, ao mesmo tempo, reconhecida como base da atividade humana e como algo a ser ultrapassado por meio desta mesma atividade, potencialmente crítica e revolucionária. ${ }^{28} \mathrm{~A}$ ética, neste sentido, de acordo com Lukács, tem um papel essencialmente mediador na conformação da práxis social e da sociedade como um todo, questão importante ao tratar dos meandros do ser social.

Lukács, ao tratar do Direito, assevera que "pode-se dizer que a ética constitui nas práticas humanas um centro mediador entre o Direito puramente objetivo e a moralidade puramente subjetiva” (LUKÁCS, 1966, p. 220). Ou seja, entre a "moralidade puramente subjetiva" e o "Direito puramente objetivo" encontra-se a estruturação complexa da atividade humana. Ela, em Lukács, é justamente tratada na Ontologia, que - ao passar pela especificidade de cada complexo social - daria base para uma Ética. A esfera da ética, assim, possui bastante importância em Lukács, porque é ela que poderia tratar da atividade humana ao compreender os elos intermediários colocados nos "hábitos”, “costumes” e mesmo na “educação”. Todos estes poderiam servir para que se tivesse o reconhecimento do capitalismo e das "exigências desse modo de produção como leis naturais e evidentes por si mesmas.” Uma "práxis comunista no presente... e no futuro", a ser tratada em uma ética, no entanto, traria decidida e justa-

a objetividade ontológica dos próprios valores. (Em contextos subsequentes deste capítulo, voltaremos a tratar desse assunto, mas só na Ética poderemos fazê-lo de modo realmente concreto)" (LUKÁCS, 2012, p. 341).

${ }^{28}$ Como aponta Lukács sobre o assunto: "uma verdadeira ética deve sempre admitir a neutralidade ontológica da legalidade do ser social em sua universalidade, ou, melhor dizendo, só pode descobrir e esclarecer as categorias que lhe são peculiares sobre a base da complexa dupla face do ser social [...]” (LUKACS, 2012, p. 365). 
mente o oposto disso. Ou seja, as tarefas de uma ética, como pensada por Lukács, seriam hercúleas, mas, principalmente diante de uma "práxis comunista no presente... e no futuro”, seriam bastante necessárias à crítica real e efetiva da sociedade existente.

\section{7 ÉTICA, DIREITO E A CRÍTICA AO CAPITALISMO EM LUKÁCS}

Temos aqui ponto importante: segundo Mészáros (2002), este caráter hercúleo da esfera ética teria uma razão objetiva: a ausência de problematização e crítica concretas do autor da Ontologia quanto ao stalinismo. Isto, no entanto, não pode ser considerado verdadeiro (SARTORI, 2016a). Primeiramente porque, como vimos anteriormente, Lukács, com sua ética, pretende justamente criticar o stalinismo ao tratar das mediações reais e efetivas que se colocam na conformação do todo social. Em segundo lugar, isso se dá ao passo que o autor remete à esfera da eticidade, de modo a tratar justamente da conformação objetiva da sociedade, inclusive problematizando e criticando suas instituições, como o Estado (SARTORI, 2016a), o Direito (SARTORI, 2010, 2015a, 2015b) e a democracia burguesa; neste sentido específico, a ética lukacsiana passa longe de decorrer de qualquer "falta de mediações políticas” (MÉSZÁROS, 2002); antes, ela indica a necessidade de passar por estas ao tratar da própria questão do “que fazer”. Também, neste sentido, a ética tem um papel importante na afirmação do materialismo lukacsiano. ${ }^{29}$

\footnotetext{
${ }^{29}$ Claro, não nos referimos ao materialismo mecanicista. Sobre a correção deste último com uma ética, esclarece Lukács: “o fato de o egoísmo racional da ética revelar-se como um prolongamento da concepção objetiva materialista (mecanicista-materialista) da natureza, ou de que nele existam efetivamente determinados elementos de uma teoria materialista da sociedade, de modo algum atenua essa contraditoriedade - antes, agrava-a” (LUKÁCS, 2012, p. 185).
} 
Uma outra questão bastante importante diz respeito à ligação da ética a esferas que, usual e cotidianamente, não são problematizadas, como o hábito, a tradição e as distintas figuras da educação. Se Marx mencionou a questão em $O$ capital, Lukács não é silente sobre o tema. Estas esferas são vistas como centrais pelo autor ao se levar em conta a conformação real e efetiva da sociedade civil-burguesa. Em uma passagem importante, o autor húngaro correlaciona a questão do hábito à sociabilidade capitalista de modo decisivo, deixando clara sua crítica ao último:

No capitalismo, a criação do hábito significa, assim, um processo geral de obscurecimento. Os homens concebem a espontaneidade como natural e normal, e aprendem a reagir às suas manifestações tal como se reage a um temporal ou ao calor intenso, isto é, a eventos naturais que podem certamente ser desagradáveis, e que podemos eventualmente detestar, mas que devem ser considerados tais como são (LUKÁCS, 2010b, p. 118-119).

O capitalismo, informa Lukács, não poderia trazer uma forma de atividade que retira de campo as potências sociais que conformam o fenômeno do estranhamento; antes, ter-se-ia o contrário: um reforço diuturno das diversas formas pelas quais se apresenta este fenômeno. Neste sentido, talvez seja possível concordar com Heller que, antes de mudar de posição e tornar-se antimarxista, acrescenta que "a vida cotidiana de todas as esferas da realidade é aquela que mais se presta ao estranhamento" (HELLER, 1972, p. 37). O hábito está intimamente relacionado à vida cotidiana e, com ele, há certa conformação de uma "normalidade", que não deixa de fornecer a base para o Direito (SARTORI, 2010). Neste sentido específico, também, ilumina-se a afirmativa lukacsiana segundo a qual "um sistema jurídico não pode funcionar muito tempo se não tem nada a ver com as concepções éticas de um povo. A afirmação oposta parte de uma abstração conceitual e historicamente falsa”. 
A espontaneidade, e a unidade imediata entre teoria e práxis que caracterizam o cotidiano (LUKÁCS, 1966), dão uma fundamentação importante para o funcionamento de um "sistema jurídico", o qual, no capitalismo, somente se coloca como tal na medida em que traz certa naturalização de mediações irracionais. ${ }^{30}$ Elas, por sua vez, e de acordo com Lukács, são tomadas como parâmetro para o atuar moral e para o funcionamento do Direito positivo. Se a moral perpassa, até certo ponto, a atividade humana, é preciso considerar que, com uma visão reta da realidade efetiva, em verdade, "o posto central do dever-ser é eliminado também no mundo da práxis”. Para Lukács, isso significa que trazer a moral como algo essencial implica certa hipostasia do dever-ser e determinada naturalização da realidade efetiva do capitalismo. Com uma teorização que tivesse por central a ética, seria possível o percurso oposto. Diz Lukács em suas notas: "ética em desenvolvimento a) Impassível rejeição (por vezes mero mal-estar) contra costumes, Direito, moral e política” (LUKÁCS, 2015, p. 205). Deste modo, pode-se afirmar que, em uma ética em desenvolvimento, justamente a crítica à espontaneidade e ao estranhamento cotidiano é central. Este é, no final das contas, o projeto lukacsiano. A questão do "que fazer" não deixa de remeter a isto também.

Lukács ainda aponta, reforçando seu materialismo: "Ad Ética e ontologia. Impossível colocar-se o ético sem adicionar condição do mundo" (LUKÁCS, 2015, p. 193). Deste modo, para o autor húngaro, justamente, trata-se de ver real e efetivamente o modo pelo qual se pode transformar as condições sociais que levam à situação em que o hábito, a espontaneidade e a vida cotidiana colocam-se como "eventos naturais que podem

\footnotetext{
${ }^{30}$ Afirma Marx: "as mediações das formas irracionais em que determinadas condições econômicas aparecem e praticamente se acoplam não importa nem um pouco para os portadores práticos dessas condições econômicas em sua ação diuturna; e já que eles estão acostumados a se movimentar no meio delas, não ficam nem um pouco chocados com isso. Uma perfeita contradição não tem nada de misterioso para eles. Nas formas fenomênicas que perderam a coerência interna e que, tomadas em si, são absurdas, eles se sentem tão à vontade como um peixe na água” (MARX, 1985, p. 241).
} 
certamente ser desagradáveis, e que podemos eventualmente detestar, mas que devem ser considerados tais como são". Neste sentido específico, há uma correlação íntima entre a teorização lukacsiana sobre a ética e sua crítica à vida cotidiana da sociedade capitalista. Sua postura, deste modo, coloca-se contra aqueles que não problematizam a espontaneidade do desenvolvimento social de uma época e, com isso, figuram como "dogmáticos": "Minha luta guerrilheira contra o dogmatismo não apenas salvou a minha relação com a vida e seus objetos, mas também a promoveu. Se hoje posso trabalhar numa estética e sonhar com a elaboração de uma ética, devo-o a esta luta” (LUKÁCS, 2008, p. 51).

Tanto a ética quanto a estética lukacsianas parecem trazer um tom contrário ao dogmatismo, de tal modo que, se o autor é explícito ao trazer certa "missão desfetichizadora” da arte por central (LUKÁCS, 1966; TERTULIAN, 2008), tal caráter contrário ao fetichismo da vida cotidiana mostra-se presente na ética lukacsiana. Mesmo que se trate de uma ética incompleta e em desenvolvimento, isto resta claro pelo que apresentamos supra. A resposta ao dogmatismo, em Lukács, portanto, remete não ao Direito ou à moral, mesmo que estes fossem compreendidos de modo “crítico". Em verdade, a questão central para o autor é a conformação de mediações sociais que permitam que os homens rompam com potências estranhadas que conformam o domínio do capital, e isto somente seria possível com a crítica ao capitalismo e com o socialismo:

O socialismo é a primeira formação econômica na história que não produz espontaneamente o homem econômico que se encaixe de modo apropriado nessa formação. Isso se dá porque se trata de uma formação de transição, claro - um interlúdio da passagem do socialismo ao comunismo. Agora, porque a economia socialista não produz e reproduz espontaneamente $o$ homem adequado a tal formação, como a clássica sociedade capitalista gerou seu homo economicus, o homem dividido de 1793 e de Sade, a função da sociedade socialista é precisamente a educação de seus membros frente ao socialismo. Essa função é sem 
precedentes, e não tem analogias com nada na democracia burguesa.

É claro que o que se precisa hoje é do renascimento dos Sovietes (LUKÁCS, 1971, p. 50).

Enquanto na sociedade capitalista os homens aparecem, em geral, como personificações e portadores (Träger) de relações sociais estranhadas, o mesmo não aconteceria no socialismo. A virtude principal da superação do capitalismo seria justamente conseguir se opor a tais potências em meio à atividade social - "socialismo: recuo do estranhamento pela extensão da objetivação - lugar d. Ética” (LUKÁCS, 2015, p. 63); “socialismo como recuo do estranhamento (pelo desenvolvimento da objetivação e alienação): Ética” (LUKÁCS, 2015, p. 79) -; neste sentido, a individualidade poderia ter um novo desenvolvimento posterior ao capitalismo, o que remeteria à supressão da mencionada oposição entre bourgeois e citoyen. A atividade do homem poderia, inclusive, trazer consigo a supressão desta oposição, a qual marcaria tanto as revoluções burguesas quanto Sade (SARTORI, 2016a). O autor da Ontologia ainda afirma que "a crise da economia escravagista, a dissolução da pólis com sua ética da cidadania, já na fase então dada do desenvolvimento social objetivo, levavam a uma primeira forma de individualidade” (LUKÁCS, 2010a, p. 254) e, assim, pelo que se nota, com a crise da sociabilidade burguesa, tem-se também uma nova ética em desenvolvimento. Esta última, tal qual na dissolução da escravidão, traz, enquanto possibilidade, uma forma de individualidade qualitativamente superior. Na sociedade que defende Lukács, uma sociedade de transição, tem-se que a "economia socialista não produz e reproduz espontaneamente o homem adequado a tal formação, como a clássica sociedade capitalista gerou seu homo economicus"; neste sentido, trata-se de buscar um modo prático de suprimir um cotidiano e uma forma de hábito que estão perpassados pelo estranhamento. A questão perpassa questões que remetem à eticidade, como aquela da formação e da educação: "a função da sociedade socialista é precisamente a educação de seus membros frente ao socialismo". 
E isso somente seria possível com algo bastante distinto do stalinismo: o renascimento dos sovietes, que é acompanhado pela participação ativa dos "de baixo".

\section{APONTAMENTOS FINAIS: Ética e Crítica ao Direito em Lukács}

Com isso, passando pelo estudo da ética, em Lukács, ter-se-ia a necessidade de uma "democracia socialista", uma "democracia da vida cotidiana”. A solução lukacsiana para a degeneração do "socialismo soviético" está nisto, pois: na conformação de uma nova “eticidade” (mesmo que o termo não seja central ao autor, tomamos a liberdade de utilizá-lo neste contexto), o que implica autogestão na produção e retomada dos sovietes enquanto órgãos que trariam uma forma de participação “de baixo”, e que suprimiria o Estado (SARTORI, 2016a). A questão é central e pode ser vista também na medida em que, com ela, ao contrário do que se poderia supor de imediato, não se tem nenhum elogio ao Direito, nem mesmo na forma de um "Direito socialista": Lukács destaca ser central "o domínio da ética pelo fenecimento do Direito e da Moral” (LUKÁCS, 2015, p. 69). Deste modo, fica clara a postura lukacsiana contrária ao domínio do jurídico sobre o social; se o autor defende a necessidade de "afirmar, teórica e praticamente, a prioridade do conteúdo político-social em relação à forma jurídica” (LUKÁCS, 2007, p. 57), isso se dá também enquanto se percebe que este "conteúdo político-social” aparece, sobretudo, naquela esfera que Hegel chamou de "eticidade”. Por isso, pode valer a pena, na filosofia do Direito, voltarmos os olhos ao marxismo lukacsiano, mesmo para aqueles que não aceitam a posição do autor.

O elo intermediário que a ética tem na Ontologia lukacsiana traz justamente este sentido: a questão do "que fazer" somente pode ser colocada com a apreensão da especificidade de cada complexo social. Esta apreensão figura, por sua vez, como mediação da atividade humana em 
meio à conformação objetiva da sociedade. Para Lukács, voltar-se à moral significaria trazer à tona uma posição idealista, em que se tem a "centralidade do dever-ser” e não da efetividade (como na ética). A moral, porém, seria um elo na práxis social, precisando ser superada rumo à concretude do ser social, à ética. A postura oposta seria inaceitável: "stalinismo reconversão da moral em Direito. Paralisia. Dificuldade do pôr a questão ética” (LUKÁCS, 2015, p. 175). Dar um enfoque jurídico seria algo extremamente problemático também - percebe-se. Não só porque a posição moral e a jurídica aparecem bastante entrelaçadas (SARTORI, 2015a), e de modo “imobilizador”, mas porque justamente o Direito, em verdade, traria o oposto da apreensão reta da realidade efetiva; em seu desenvolvimento, ele traria um ímpeto bastante manipulatório que, na medida mesma em que procura apreender o movimento do real, o deixa escapar. $\mathrm{O}$ autor húngaro menciona a "discrepância necessária entre Direito e realidade econômico-social” (LUKÁCS, 2013, p. 238) - que perpassa o "duplo caráter do reflexo jurídico" (SARTORI, 2010) - e acrescenta que:

O funcionamento do direito positivo está baseado, portanto, no seguinte método: manipular um turbilhão de contradições de tal maneira que disso surja não só um sistema unitário, mas um sistema capaz de regular na prática o acontecer social contraditório, tendendo para a sua otimização, capaz de mover-se elasticamente entre polos antinômicos - por exemplo, entre a pura força e a persuasão que chega às raias da moralidade -, visando implementar, no curso das constantes variações do equilíbrio dentro de uma dominação de classe que se modifica de modo lento ou acelerado, as decisões em cada caso mais favoráveis a essa sociedade, que exerçam as influências mais favoráveis a práxis social. Fica claro que, para isso, faz-se necessária uma técnica de manipulação bem própria, o que já basta para explicar o fato de que esse complexo só é capaz de se reproduzir se a sociedade renovar constantemente a produção de "especialistas" (de juízes e advogados até policiais e carrascos) necessários para tal. Porém, a tarefa social vai ainda mais longe (LUKÁCS, 2013, p. 247). 
O modo pelo qual o "reconhecimento oficial" e a "eticidade" se relacionam é claro, segundo Lukács: tem-se uma postura manipulatória que, em meio ao desenvolvimento do complexo jurídico, vem a adaptar-se às “decisões em cada caso mais favoráveis a essa sociedade” em que opera um sistema jurídico dado. O Direito seria um complexo social característico de uma forma de "otimização" estranhada e marcada por uma normatividade inseparável de um "processo geral de obscurecimento". Se "um sistema jurídico não pode funcionar muito tempo se não tem nada a ver com as concepções éticas de um povo”, isso se dá na medida em que o Direito é capaz de "mover-se elasticamente entre polos antinômicos" que vão da violência à moral; neste sentido, as "concepções éticas de um povo" precisam sempre ser manipuladas para que isto se dê e para que a sociabilidade existente seja vista de tal modo que as pessoas tenham tudo como "natural e normal, e aprendem a reagir às suas manifestações tal como se reage a um temporal ou ao calor intenso"; segundo Lukács, a centralidade do dever, colocada na moral, tem como correlata a manipulação trazida na esfera jurídica, sendo necessário voltar-se à esfera que se coloca enquanto um "centro mediador" real e efetivo entre estas duas esferas, a ética. Se, com Lukács, também "pode-se dizer que a ética constitui nas práticas humanas um centro mediador entre o Direito puramente objetivo e a moralidade puramente subjetiva”, é preciso que se volte não tanto à relação existente entre moral e Direito (SARTORI, 2015a), mas à relação entre ética e o último.

Se formos dar crédito ao que salienta o autor húngaro, isso seria preciso até mesmo para que, no marxismo, fosse possível soterrar de vez o stalinismo; este também se apegaria à moral e ao Direito, em verdade. Aí, segundo Lukács, ter-se-ia justamente uma "paralisia” e a "dificuldade de pôr a questão ética”, o que faria com que a sociabilidade existente fosse vista enquanto "socialista", sem que efetivamente se rompesse com a "manipulação" que marca o "funcionamento do Direito positivo". A tarefa de uma ética marxista, portanto, remeteria tanto à crítica ao capitalismo 
manipulatório quanto ao stalinismo e suas derivações. Se é certo que o autor húngaro não pode dar cabo desta tarefa, igualmente certo é que ela é essencial a todos aqueles que acreditam que o marxismo ainda tem algo a contribuir na filosofia e na teoria do Direito.

Aponta Lukács: "Stalin: moral retorna ao Direito ao invés de avançar para a ética (consequiência: reservatio mentalis, auto-enganação, etc., foi pelo Direito naturalmente, quer pela distorção moral)” (LUKÁCS, 2015, p. 171). Segundo Lukács, as consequências da prevalência do binômio Direito-moral seriam catastróficas, portanto. A capacidade do Direito "mover-se elasticamente entre polos antinômicos" passaria longe de trazer qualquer solução para os antagonismos sociais; antes, com este complexo, e com a correlata existência do Estado, haveria certa oscilação entre polos antinômicos do ser social da sociedade civil-burguesa ${ }^{31}$ e nunca a real e efetiva supressão da última. Para que isso se desse, seria necessário questionar a própria conformação objetiva da realidade social de uma época, trazendo à tona a auto-organização da produção, uma democracia da vida cotidiana, a supressão do Estado e a supressão do Direito. Como vemos, isso perpassa a teorização lukacsiana sobre a ética que, embora bastante incompleta e fragmentária, deixa claro que não há no autor qualquer tom idealista ao se valorizar tal esfera; antes, tem-se o oposto. Também não há qualquer tom conciliatório ante o stalinismo. $\mathrm{O}$ autor húngaro, antes, é muito duro quanto a este último. Retomar a questão da ética seria central para que se rompesse decididamente com o stalinismo, justamente porque, neste último, "na práxis a atuação não é regulada pela mais profunda inteligência das coisas, ao contrário, essa mais profunda inteligência é construída em função da tática do agir” (LUKÁCS, 1986, p. 63). Esta superação implicaria colocar a questão do "que fazer" justamente tendo

${ }^{31}$ Neste ponto, adotamos a postura de Mészáros segunda a qual na URSS ainda haveria uma forma de capital e, portanto, uma forma específica de sociedade civil-burguesa (MÉSZÁROS, 2002). 
em conta uma "profunda inteligência das coisas", em que a especificidade de cada complexo social é deixada clara a ponto de ser possível se pensar em uma democracia da vida cotidiana, em que a eticidade deixa de ser algo conformado espontânea e estranhadamente. Para Lukács "a tarefa da democracia socialista é penetrar realmente na inteira vida material de todos os homens, desde a cotidianidade até as questões mais decisivas da sociedade; é dar expressão à sua sociabilidade enquanto produto da atividade pessoal de todos os homens" (LUKÁCS, 2008, p. 117). Isso, claro, envolveria ponderações essenciais sobre a ética.

\section{REFERÊNCIAS}

ALBINATI, Ana Selva Castelo Branco. Marx, leitor de Demócrito e Epicuro. In: Verinotio: revista on-line de Educação e Ciências Humanas, Belo Horizonte, n. 3, 2005.

ALCÂNTARA, Norma. Ontologia e alienação. São Paulo: Instituto Lukács, 2014.

ANDRADE, Mariana. Ontologia, dever e valor em Lukács. Maceió: Coletivo Veredas, 2016.

CHASIN, José. Marx: estatuto ontológico e resolução metodológica. São Paulo: Boitempo, 2009.

DWORKIN, Ronald. A justiça de toga. Tradução Jefferson Luis Camargo. São Paulo: Martins Fontes, 2010.

- O império do Direito. Tradução Jefferson Luiz Camargo. São Paulo: Martins Fontes, 2014.

. Levando os direitos a sério. São Paulo: Martins Fontes, 2007.

GOMES, David; CATTONI DE OLIVEIRA, M. A. Constitucionalismo e dilemas da justiça. Belo Horizonte: Initia Via, 2014.

HABERMAS, Jürgen. Agir comunicativo e razão descentralizada. Tradução L. Aragão. Rio de Janeiro: Tempo Brasileiro, 2002. 
Direito e democracia. Entre a facticidade e a validade. Tradução Flávio Beno Siebeneichler. Rio de Janeiro: Tempo Brasileiro, 2003. V. I.

. Direito e democracia. Entre a facticidade e a validade. Tradução Flávio

Beno Siebeneichler. Rio de Janeiro: Tempo Brasileiro, 1997. V. II.

HART, Herbert L. A. O conceito de Direito. Tradução A. Ribeiro Mendes. Lisboa: Fundação Calouste Gulbenkian, 2003.

HEGEL, G. W. Princípios da filosofia do Direito. Tradução Orlando Vittorino. São Paulo: Martins Fontes, 2003.

HELLER, Agnes. Cotidiano e história. Tradução Carlos Nelson Coutinho e Leandro Konder. Rio de Janeiro: Paz e Terra, 1972.

. Para mudar a vida cotidiana: felicidade, liberdade e democracia. Tradução Carlos Nelson Coutinho. São Paulo: Brasiliense, 1982.

HONNETH, Axel. O direito da liberdade. São Paulo: Martins Fontes, 2015.

. Reification: a new look to an old idea. Oxford: Oxford Press, 2012.

LENIN, V. I. O Estado e a revolução. Tradução Aristides Lobo. São Paulo: Expressão Popular, 2010.

LOPES, Antonio José. A questão do Standpunkut na concepção de cientificidade marxiana. In: Revista On-Line de Filosofia e Ciências Humanas, Belo Horizonte, n. 12, 2010. Disponível em: <www.verinotio.org>.

LÖWY, Michael. A evolução política de Lukács. São Paulo: Cortez, 1998.

LUKÁCS, György. Conversando com Lukács. Tradução Giseh Vianna Konder. Rio de Janeiro: Paz e Terra, 1969.

. Lukács on his Life and Work. New Left Review I/68. London, 1971.

. Conversation with Gyorgy Lukács (Interview with Franco Ferrarotti). In: World View, New York, maio 1972.

. Diálogo sobre o pensamento vivido. In: Ensaio 15-16. Tradução Equipe Ensaio. São Paulo: Ensaio, 1986.

El Joven Hegel: y los problemas de la sociedad capitalista. Tradução Manuel Sacristan. Mexico: Grijalbo, 1963. 
Escritos de Moscu: estúdios sobre literatura y politica. Tradução Martín Koval e Miguel Vedda. Buenos Aires: Gorla, 2011.

Estética, La Peculiaridad de lo Estético. Tradução Manuel Sacristan.

México: Ediciones Grijalbo, 1966. V. III - Questiones Preliminares y de Princípio.

. L'Estraniazone, Ontologia Dell'Essere Sociale II. Trad. Maria Norma Alcântara Brandão de Holanda e Sergio Lessa. Roma: Riuniti, 1981. Disponível em: <http://www.sergiolessa.com>. Acesso em: 24 fev. 2008.

. Marxismo e teoria da literatura. Tradução Carlos Nelson Coutinho. São Paulo: Expressão Popular, 2010b.

Notas para uma ética. Tradução Sérgio Lessa. Alagoas: Instituto Lukács, 2015.

. O jovem Marx e outros escritos filosóficos. Tradução Carlos Nelson Coutinho e José Paulo Netto. Rio de Janeiro: UFRJ, 2007.

. Ontologia do ser social, a falsa e a verdadeira ontologia de Hegel. Tradução Carlos Nelson Coutinho. São Paulo: Livraria Editora Ciências Humanas, 1979.

. Posfácio de 1967. In: História e consciência de classe. Tradução Rodnei Nascimento. São Paulo: Martins Fontes, 2003.

. Prolegômenos para uma ontologia do ser social. Tradução Nélio Schneider. São Paulo: Boitempo, 2010a.

. Para uma ontologia do ser social I. Tradução Carlos Nelson Coutinho, Mario Duayer e Nélio Schneider. São Paulo: Boitempo, 2012.

. Para uma ontologia do ser social II. Tradução Nélio Schneider. São Paulo: Boitempo, 2013.

. Socialismo e democratização. Tradução Carlos Nelson Coutinho e José Paulo Netto. Rio de Janeiro: UFRJ, 2008.

. Tática e ética: escritos tempranos. Tradução Miguel Vedda. Buenos Aires: El Cielo por Asalto, 2005. 
. Teoria do romance. Tradução José Marcos Mariani de Macedo. São Paulo: Editora 34, 2000.

MACEDO, Ronaldo Porto. Do xadrez à cortesia. São Paulo: Saraiva, 2011.

MARX, Karl. O capital. Tradução Rubens Enderle. São Paulo: Boitempo, 2013. . O Capital, Volume V. Tradução Regis Barbosa e Flávio R. Kothe. São Paulo: Nova Cultural, 1985.

MÉSZÁROS, István. Lukács' concept of dialetic. London: Merlin Press, 1972. . Para além do capital: rumo a uma teoria da transição. Tradução Paulo Cezar Castanheda e Sérgio Lessa. São Paulo: Boitempo, 2002.

MUÑOZ, Alberto Alonso. Transformações na teoria do direito contemporânea. São Paulo: Quartin Latin, 2008.

NETTO, José Paulo. Apresentação. In: LUKÁCS, György. Para uma ontologia do ser social I. Tradução Carlos Nelson Coutinho, Mario Duayer e Nélio Schneider. São Paulo: Boitempo, 2012.

PACHUKANIS, E. P. Teoria geral do direito e o marxismo. Tradução Paulo Bessa. Rio de Janeiro: Renovar, 1988.

PATRIOTA, Reiner. Apresentação. In: LUKÁCS, György. Der Spigel entrevista o filósofo Lukács. Tradução Rainer Patriota. In: Verinotio: Revista On-Line de Educação e Ciências Humanas, Belo Horizonte, n. 9, 2008. Disponível em: $<$ www.verinotio.org $>$.

RODRIGUES, José Rodrigo. Como decidem as cortes? Para uma crítica ao Direito brasileiro. São Paulo: FGV, 2013.

ROSENZWEIG, Franz. Hegel e o Estado. Tradução Ricardo Timm de Souza. São Paulo: Perspectiva, 2008.

SARTORI, Vitor Bartoletti. A questão da crítica ao direito à luz da obra madura de Lukács. In: TORRIGLIA, Patrícia Laura et al. (Org.). Ontologia e crítica do tempo presente. Florianópolis: Em debate, 2015b.

. Hermenêutica filosófica e marxismo: sobre uma peculiar "ausência-presença”. In: Revista Pensar, Fortaleza, 2016c.

. Lukács e a crítica ontológica ao Direito. São Paulo: Cortez, 2010. 
. Lukács e a questão da técnica em Heidegger. Verinotio: Revista On-

-Line de Educação e Ciências Humanas, Belo Horizonte, n. 13, 2012. Disponível em: <www.verinotio.org $>$.

. Lukács e as figuras da política na sociedade capitalista: apontamentos sobre Democracia e Liberalismo. Prima Facie, João Pessoa: UFBP, v. 15, n. 28,2016 .

. Lukács e Heidegger: a ontologia do século xx diante de Hegel. In: VEDDA, Miguel; COSTA, Gilmaísa; ALCANTARA, Norma (Org.). Anuário Lukács 2016. Maceió: Instituto Lukács, 2016b.

Moral, ética e direito: Lukács e a teoria do direito. Belo Horizonte: Sapere Auede, 2015a.

. De Hegel a Marx: da inflexão ontológica à antítese direta. Kriterion, n. 130. Belo Horizonte, 2014.

STRECK, Lenio. Hermenêutica jurídica e $(m)$ crise. Porto Alegre: Livraria do Advogado, 1999.

TERTULIAN, Nicolas. Pósfácio. In: LUKÁCS, György. Prolegômenos para uma ontologia do ser social. Tradução Nélio Schneider. São Paulo: Boitempo, 2010.

Lukács: etapas de seu pensamento estético. Tradução Renira Lisboa de Moura Lima. São Paulo: Ed. Unesp, 2008.

. Lukács e o stalinismo. Tradução Ronaldo Vielmi Fortes. In: Verinotio:

o7 Revista On-Line de Educação e Ciências Humanas, Belo Horizonte, n. 11, 2007b. Disponível em: <www.verinotio.org >.

. Lukács e seus contemporâneos. Tradução Pedro Corgozinho. São Paulo: Perspectiva, 2016.

. O pensamento do último Lukács. Tradução Juarez Duayer. Revista Outubro, São Paulo, n. 16, 2007a.

VAISMAN, Ester; FORTES, Ronaldo Vielmi. A politicidade no pensamento tardio de György Lukács. Revista Estudos Políticos, v. 5, n. 1. Rio de Janiero: UFRJ, 2014.

VARGA, Csaba. The place of Law in Lukács' world concept. Tradução Judir Petrányi e Sandor Eszenyi. Budapest: Szent Istvàn Tarsulat, 2012. 